IZA DP No. 4585

Nature, Nurture and Egalitarian Policy:

What Can We Learn from Molecular Genetics?

Petter Lundborg

Anders Stenberg

November 2009 


\title{
Nature, Nurture and Egalitarian Policy: What Can We Learn from Molecular Genetics?
}

\author{
Petter Lundborg \\ VU University Amsterdam, Tinbergen Institute, \\ Lund University and IZA
}

Anders Stenberg

SOFI, Stockholm University

\section{Discussion Paper No. 4585 \\ November 2009}

\author{
IZA \\ P.O. Box 7240 \\ 53072 Bonn \\ Germany \\ Phone: +49-228-3894-0 \\ Fax: +49-228-3894-180 \\ E-mail: iza@iza.org
}

Any opinions expressed here are those of the author(s) and not those of IZA. Research published in this series may include views on policy, but the institute itself takes no institutional policy positions.

The Institute for the Study of Labor (IZA) in Bonn is a local and virtual international research center and a place of communication between science, politics and business. IZA is an independent nonprofit organization supported by Deutsche Post Foundation. The center is associated with the University of Bonn and offers a stimulating research environment through its international network, workshops and conferences, data service, project support, research visits and doctoral program. IZA engages in (i) original and internationally competitive research in all fields of labor economics, (ii) development of policy concepts, and (iii) dissemination of research results and concepts to the interested public.

IZA Discussion Papers often represent preliminary work and are circulated to encourage discussion. Citation of such a paper should account for its provisional character. A revised version may be available directly from the author. 
IZA Discussion Paper No. 4585

November 2009

\section{ABSTRACT \\ Nature, Nurture and Egalitarian Policy: What Can We Learn from Molecular Genetics?}

This brief paper draws attention to molecular genetic research which may provide a new dimension to our understanding of how socioeconomic outcomes are generated. In particular, we provide an overview of the recently emerging evidence of gene-environment interaction effects. This literature points out specific policy areas which may compensate individuals carrying genetic risks, without resorting to gene mapping of the population. Such policies would also increase intergenerational mobility if genetic and/or environmental risk factors are more common in socially disadvantaged groups.

JEL Classification: $\quad$ J62, H50

Keywords: gene, environment, interaction, molecular genetics, inequality

Corresponding author:

Anders Stenberg

SOFI

Stockholm University

SE-106 91 Stockholm

Sweden

E-mail: anders.stenberg@sofi.su.se 


\section{Introduction}

Economists have shown an increased interest in quantitative genetics, i.e. how genetic endowments co-vary with earnings, education or human behavior. The hereditary components reported for education have been between .45 and .65 and for earnings between .25 and .40 (e.g. Behrman and Taubman 1976, 1989, Taubman 1976, Plug and Vijverberg 2003, Björklund, Lindahl and Plug 2006, Björklund, Jäntti and Solon 2005, 2007, Sacerdote, 2002, 2007, Liu and Zeng 2009) while about .20 of the variation in personal traits such as risk-taking and overconfidence is explained by heritage (Cesarini et al. 2009a, 2009b). These studies have contributed greatly to the acceptance and understanding that genes play an important role in explaining various outcomes (or phenotypes). Methodologically, they adhere to a tradition which spans over a number of academic fields, where genetic variation is indirectly identified by analyzing intergenerational transmissions in families with adopted children, or by comparing correlations of monozygotic (MZ) twins with those of dizygotic (DZ) twins.

The estimated nature components include direct genetic effects $(G)$, interactions between different gene types $(\mathrm{GxG})$ and gene environment correlations (rGE). The latter reflects that the definition of nature encompasses the genetic influence on the individual's environment (e.g. due to their genetic similarity, MZ twins are treated more similarly than DZ twins and they may also generate their own environments more similarly than DZ twins). ${ }^{1}$ Further, if the sensitivity to genetic risk is conditional on some environmental factor, the estimated nature components also capture gene environment interaction effects (GxE henceforth). ${ }^{2}$ These aspects, and others, have made the interpretation of traditional heritability estimates a subject of debate as it is unclear to what extent they reflect environmental factors. ${ }^{3}$ Consequently, in terms of specific policy implications, quantitative genetics is generally silent. However, many governments redistribute resources on the basis of genetic endowments. Medications are subsidized for individuals with chronic diseases, disabled are entitled to extra public resources; dyslectic pupils are offered extra teaching assistance etc. Individuals could in these cases be said to be identified as carriers of genetic risks (through their behaviors/symptoms), and compensated by environmental improvements in the form of medication, equipment and/or teaching hours. ${ }^{4}$

Recent molecular genetic research sheds new light on how genes operate by directly observing individuals' genetic variants and their associations with

\footnotetext{
${ }^{1}$ Put differently, rGE reflect that the probability of a experiencing a specific E differs for different $\mathrm{G}$.

${ }^{2} \mathrm{GxE}$ reflect that the sensitivity to a specific E differs for different G. GxE has been addressed within the tra-ditional framework of quantitative genetics (e.g. Turkheimer et al. 2003, Björklund, Lindahl and Plug 2006), we discuss these in Section 2.

${ }^{3}$ From a number of different perspectives, authors have made critical assessments of heritability estimates based on traditional models (e.g. Goldberger 1979, Jencks 1980, Scarr and Weinberg 1994, Stoolmiller 1999, Smith et al. 2000, Case et al. 2000, 2001, Dickens and Flynn 2001, Joseph 2002, Rutter and Silberg 2002, Horwitz et al. 2003, Richardson and Norgate 2006, Heckman 2007, 2008, Cunha and Heckman 2009).

${ }^{4}$ Market solutions may of course also compensate genetic differences, e.g. we buy glasses to improve poor eyesight (Goldberger 1979).
} 
outcomes. In the last decade or so, this literature has uncovered an increasing amount of evidence of GxE which, together with epigenetic research (to be explained below), has challenged the traditional view of separating between effects of genes and environments. The GxE evidence suggests that a given gene-outcome association surprisingly often only holds conditional on some environmental risk factor. Hence, if carriers of a genetic risk suffer disproportionately in a certain environment, a policy which reduces the prevalence of the harmful environment will compensate this group of individuals without resorting to gene mapping of the population.

The purpose of this article is to provide an overview of the emerging $\mathrm{GxE}$ evidence in molecular genetic research, assess identification issues and discuss possible policy implications. For economists and other researchers concerned with how socioeconomic outcomes are generated, the overview and assessment of this branch of literature may serve to increase the understanding of the nature-nurture interplay. ${ }^{5}$ Taken at face value, the GxE evidence point out environmental risk factors (examples are given in a moment) which policy may subdue to enhance outcomes of those carrying the genetic risk. Such policies would also increase the intergenerational mobility in a society, under the plausible assumption that individuals in low socioeconomic groups are more likely to be exposed to environmental and/or genetic risk factors. Thus, if a detrimental environment has unequal effects, which systematically depend on the genetic heritage of individuals, there is increasing impetus for an egalitarian policy maker to offset the environmental risk. ${ }^{6}$

One strand of molecular genetic research singles out genetic variants, often derived from experimental evidence on animals, to test hypotheses of a statistical association with some personality trait or disease. Since 2005, so-called genome-wide association studies (GWAS) have made it possible to examine hundreds of thousands of genetic variants and their associations with individual traits (Pearson and Manolio 2008 provide an introduction to GWAS, see also the webpage of the National Human Genome Research Institute). A number of different diseases have been linked to genetic variants but the estimated effects have been tiny (Hirschhorn 2009, Goldstein 2009). Given that traditional studies frequently have indicated heritability estimates in excess of .60 for height, IQ and hyperactivity disorders ADHD, geneticists have been somewhat surprised that identified gene associations, including accumulated effects of multiple genes, only explain about 3 per cent of the variation in a trait such as height (Weedon et al. 2008), and even less of the variation in IQ scores (Butcher et al. 2008, Meaburn et al. 2008) and in ADHD (Franke et al. 2009, Wallis et al. 2008, Thapar and Stergiakouli 2008). Several hypotheses have been put forward to explain the weakness of the findings. It may be that outcomes are affected by a large number of gene types in combination, and that these combinations need to be identified, or that the important genetic

\footnotetext{
${ }^{5}$ None of the economic papers on quantitative genetics mentioned in the beginning refer to the recent molecular genetic research. In their analysis of the origins of inequality, Cunha and Heckman (2009, p330) acknowledge the GxE literature but they do not discuss the evidence or its implications.

${ }^{6}$ To be precise, the GxE evidence implies that inequality is reduced across "genetic groups" if individuals carrying a genetic risk benefit more from an improved $\mathrm{E}$ than individuals without genetic risk.
} 
variants are rare, making it necessary with very large samples for statistical power.

Meanwhile, researchers with access to detailed data on genes and environments have explored hypotheses based on the idea that outcomes are influenced by genes, but only conditional on some environmental risk. This research uses experimental evidence on animals as guidance to find relevant genetic risk factors. The reported results have had a profound impact on the field. ${ }^{7}$ In a seminal paper, Caspi et al. (2002) showed that antisocial behavior in adulthood, such as criminal activity, was associated with the interaction of childhood maltreatment and a low prevalence of a specific gene variant, but not separately by the gene. In a similar mould, Caspi et al. (2003) found depressions to be associated with interactions between a specific gene type and earlier stressful life events and Caspi et al. (2007) reported that IQ scores were influenced by a specific gene only conditional on breastfeeding as a child. The latter study confirmed the finding by using a second data set from the UK while the former two studies have been replicated a number of times (we will return to these later). Another replicated result is that ADHD, estimated to affect more than 5 per cent of the world's school aged children (Polanczyk et al. 2007), has been linked to an interaction between a specific gene variant and prenatal maternal smoking (Kahn et al. 2003). Non-replicated findings include GxE evidence associated with schooling outcomes, sexual behaviors, political preferences and mental disorders. In addition, epigenetic research has made it fully accepted that environments may prompt genes to change their "behavior" so the influence of even temporary environmental conditions may extend to future generations (e.g. Waterland and Jirtle 2003, Mill and Petronis 2007, 2008, Foley et al. 2009). Epigenetic modifications occur independently of the DNA sequence but are heritable, meaning that the same individual passes on different heritable traits at different points in time depending on the environment.

As our exposition will show, the recent evidence of GxE is widely accepted but not full proof. We fully acknowledge that molecular genetic research on nature-nurture interplay is still in its infancy. However, already at this stage, one may infer that genetic and environmental influences are largely intertwined and that the evidence of $\mathrm{GxE}$ will continue to grow as knowledge about relevant environmental risk factors improve (e.g Caspi et al. 2004, Lehn et al. 2007, Asbury et al. 2008, Oliver et al. 2008) and as data sources of sufficient detail accumulate (e.g. Reiss, 2008, Moffitt et al. 2006, including references p8). This research is highly likely to point out areas where active policies may enhance socioeconomic equality and intergenerational mobility. To exemplify, some of the evidence presented so far imply that diminished childhood maltreatment in families would decrease the prevalence of antisocial behavior in all groups, whether carriers of genetic risk or not, but it would benefit carriers of the genetic risk more strongly. Corporal punishment of children is illegal in 23 countries (August 2009). If legislation has a normative impact which permanently decreases child maltreatment, the difference in antisocial behavior across "genetic groups" would decrease in both present and future

\footnotetext{
${ }^{7}$ Google Scholar indicates that Caspi et al. $(2002,2003)$ are cited more than 3600 times (August 2009).
} 
generations. $^{8}$ Similar implications follow if increased resources could decrease smoking and/or drinking among pregnant women (reducing the incidence of ADHD) and/or could increase mothers' breastfeeding of children (enhancing IQ). Consequently, we believe that this literature should be of interest to social scientists.

The paper is organized as follows; we present evidence of GxE from traditional models based on twins and adoptees in the following section. Section 3 contains an account of the $\mathrm{GxE}$ evidence from molecular genetic research, including a discussion on identification issues. Section 4 presents epigenetic research and Section 5 concludes.

\section{Gene environment interactions in traditional models}

Quantitative genetic studies based on twins or adoptees have found a substantial hereditary effect in most behavioral traits. In comparison, the number of articles reporting evidence of GxE within this framework is very small. ${ }^{9}$ An often cited study in the economics literature is Turkheimer et al. (2003) who demonstrated that the genetic component of the variation in IQ was higher in groups with better socioeconomic standards (SES). Splitting their sample in two halves, estimates of heritability were .10 if SES was low and .72 if SES was defined as high. Similar findings had already been reported by Rowe et al. (1999), when controlling for parents' level of education, Guo and Stearns (2002) when controlling for parental unemployment and, more recently, Harden et al. (2007) when considering parental income. On adoption data, Sacerdote (2007) divided foster families into three types and found environmental influences to be strongest in large families where parents had low educational achievements. Thus, all these results indicate that poor socioeconomic background is associated with a stronger environmental impact. A common interpretation is that genes associated with ability may be suppressed by bad environments. A key question, and a potentially important contribution of molecular genetics, is to more exactly identify the environmental risk factors.

Björklund, Lindahl and Plug (2006) used a different approach to detect GxE. In order to analyze schooling levels of children adopted in Sweden in the 1960s, they constructed interaction variables between adoptive parents' and biological parents' schooling to reflect the children's environmental and genetic factors. In alternative specifications, they used earnings, income or university attendance in similar fashion. The interaction variables were associated with significant coefficients, but counter to intuition, the main effects of the biological and rearing parents' characteristics became insignificant or even significantly negative. Björklund, Jäntti and Solon (2005) report similar

\footnotetext{
${ }^{8}$ Corporal punishment of children is illegal in Sweden since 1979. Durrant and Janson (2005) confirm that physical abuse did decrease and infer education and a normative impact of the law as two probable causes.

${ }^{9}$ For references on GxE evidence within the traditional framework, see also Rutter and Silberg (2002), Moffitt et al. (2006), McGue (2008).
} 
findings with a reduced sample from the same data. While they do not reject the idea of GxE interactions, they note that the framework does not allow for a useful decomposition of nature and nurture effects.

More specific evidence of $\mathrm{GxE}$ was reported in the studies by Cadoret et al. (1996) and Kendler et al. (1995). These partly contributed to the formulation of the hypotheses tested in the seminal work by Caspi et al. (2002, 2003). Cadoret et al. (1996) analyzed conduct disturbances among adoptees in Iowa. The measure of genetic risk was based on information about antisocial personality disorder in biological parents, and the environmental risk was measured by indicators on antisocial behavior of the rearing parents. The negative environment had no effect on the child's conduct disturbance if there was no biological risk factor involved, but the effect was significant if both conditions applied. Kendler et al. (1995) studied the incidence of major depressions within the framework of the twin model. Stressful life events among MZ and DZ twins were considered as the environmental risk factor, whereas the genetic risk was measured by the incidence of depressive behavior in the co-twin. The findings indicated that given a stressful life event had occurred, the genetic risk altered the probability for depression.

\section{Molecular genetic research}

We next turn to results from molecular genetics research, where genetic variants are directly observable. In Section 3.1, we give an account the evidence of GxE in Caspi $(2002,2003)$ and discuss issues of identification. In Section 3.2 , we present some further examples of GxE evidence but then abstain from a discussion on identification as our intention is foremost to show the range of topics where GxE has been considered.

\section{A Evidence of gene environment interaction effects}

Caspi et al. (2002 and 2003) were the first molecular genetic studies to establish gene environment interaction effects on human behavior. This team of researchers followed (and still follows) 1037 individuals from the city of Dunedin, New Zealand, born between April 1972 and March 1973. Childparent data have been collected every second year until aged 15 and then at age 18, 21, 26 and at age 32, when the sample still displayed 96 per cent retention. The longitudinal data contains details on both environmental and genetic factors. The point of departure in Caspi et al. (2002) was the hypothesis of a connection between child abuse and later antisocial behavior. Focusing on males, followed from age 3 to 26 , they explored variation in maltreatment experiences between age 3 and 11. No maltreatment was reported for 64 per cent, "probable" maltreatment for 28 per cent and "severe" maltreatment for 8 per cent. Their outcomes included five different measures of antisocial behavior; adolescent conduct disorders, convictions of violent crimes, disposition towards violence assessed at age 26 , symptoms of antisocial personality disorder at age 26 and a composite index measure of the four. Using an additive model, the composite index of antisocial behavior was not significantly associ- 
ated with the candidate gene variant $(\mathrm{n}=442$, p-value .89$) .{ }^{10}$ When including an interaction variable between genetic risk and maltreatment, a significant association with each measure of antisocial behavior was detected, including the composite index. Thus, giving the results a causal interpretation, any policy which could diminish child maltreatment would also decrease later antisocial behavior, including criminal activities, and particularly so among individuals carrying genetic risk factors. The size of the increase in probability of antisocial behavior is non-trivial when genetic risk is combined with environmental risk (as compared with only environmental risk), but a weakness is that the cells of carriers with both genetic risk and environmental risk is typically very small, below 20 individuals.

The first study to replicate the result was Foley et al. (2004) who analyzed the incidence of conduct disorder for a sample of Virginia twins (514 males). Their definition of maltreatment in childhood was based on detailed information from interviews conducted by trained field workers, and then classified as violence between parents, parental neglect or inconsistent parental discipline. Several studies have followed, and a meta-analysis by Taylor and Kim-Cohen (2007) reviews the results from published articles. They report that the GxE prediction "holds up across eight different studies with samples that range in mean age from 7 to 32 ". These include two non-replications. Haberstick et al. (2005) was based on interviews of 774 males but they were "self-nominated" (volunteers) and included only four individuals convicted of any violent offence. Huizinga et al. (2006) was the other non-replication, based on self-report questionnaires from a sample of 277 males, and we return to this study and other issues of identification below. ${ }^{11}$

Caspi et al. (2003) studied the incidence of stressful life events and its association with depression, showing that a genetic variant had a moderating impact on the relation. This topic has a long history in the psychiatric literature. Stressful life events (SLEs) between ages 21 and 26 were assessed with life-history calendars, and included 14 types of events such as job loss, financial stress, health stressors, marital problems, marital loss. In the Dunedin sample, 30 per cent experienced no SLE, 25 per cent one event, 20 per cent two events, 11 per cent three events and 15 per cent four events or more. The genetic risk factor was not significantly associated with SLEs (p-value .59). Depressive symptoms in the past year were assessed at age 26 through interviews.

Again, there was no significant occurrence of depressive symptoms across the gene type, but an interaction variable between SLE and the genetic variation was significantly linked with depressive symptoms. Uher and McGuffin (2008) review 17 published works, including three non-replications, which have attempted to replicate the study presented in Caspi et al. (2003). They explore the design of all studies in terms of statistical approaches, the definitions of environmental risk and outcome measures, and assess whether genes influence the probability of environmental risk. A statistical property when estimating

\footnotetext{
${ }^{10}$ The gene type in question is called MAO-A, but we avoid biological definitions as our interest is primarily to discuss overall implications for social policy rather than gene-specific aspects.

${ }^{11}$ One study, Young et al. (2006), was excluded from their analysis as it was based on a clinical sample of individuals in treatment for conduct problems.
} 
interaction effects in regressions is that the results are sensitive to scaling and susceptible to generate false significant as well as false insignificant estimates. In Caspi et al. (2002, 2003), robustness checks where the E factors were represented by several types of indicators with different scaling properties supported the original hypotheses.

Uher and McGuffin (2008) devote particular attention to the three nonsupportive studies of Caspi et al. (2003), which they note also reported weaker direct associations between SLE and the onset of depression. As possible explanations, they infer data collection methods and the age composition of the samples. Structured interviews have been judged as more reliable to accurately assess SLEs (Brown and Harris 1978, Paykel 1997), and while the five studies based on structured interviews replicated the findings, the non-replications were all based on self-report questionnaires (as was Huizinga et al. 2006, the non-replication of Caspi et al. 2002). Concerning the age of the samples studied, the GxE evidence may not hold for older age groups as SLEs have a naturally weaker association with depression among elderly. Depressive states tend to re-occur and the strongest link with SLE concerns the first depressive episode (Meltzer, 1989).

The GxE evidence could be driven by a gene interaction ( $\mathrm{GxG}$ ) rather than GxE. One argument against this is that the hypothesized genetic risks are derived from experimental like evidence on animals, which do not include genetic interactions (references are provided in Caspi et al. 2002, 2003, Uher and McGuffin 2008). Also, Caspi et al. (2003) found the GxE interaction was unrelated to depression reported at age 18 or age 21, i.e. in periods preceding the SLE. Thus, if GxG is a confounding factor, it is likely to work through the SLE. ${ }^{12}$ The same is implied by the insignificant correlation between gene type and the occurrence of SLE. Caspi et al. (2002) also show that none of the $\mathrm{E}$ factors in that study (the measures of child maltreatment) correlate significantly with the candidate $\mathrm{G}$ factor. However, to be able to completely exclude the GxG hypothesis, one would need a randomly distributed SLE, but the GxE evidence presented so far does not include environmental risk which has been randomly assigned.

Additional results in Caspi et al. (2003) reported that child maltreatment as $\mathrm{E}$ factor (instead of SLE) generated significant GxE for the incidence of depression, emphasizing that $\mathrm{GxE}$ is not limited to a narrow environmental adversity. Other studies have altered the depressive state outcome to instead focus on criminal behavior, alcohol and drug use (Reif et al. 2007, Covault et al. 2007, Nilsson et al. 2005, Kaufman et al. 2007). The results imply a complex set of effects of GxE for which Uher and McGuffin (2008) suggest three possible interpretations. It may be 1) that the same GxE has several separate effects, or 2) that the same GxE contributes to several outcomes along the same causal pathway (depression leads to substance use, which leads to criminality), or 3) that there is some intermediate outcome which is connected in a causal link between gene type and several different outcomes. These

\footnotetext{
${ }^{12}$ Kendler et al. (1999a, 1999b) established a causal relation between SLE and depression. Depending on the nature of the SLE, genetic heritage (controlled by using MZ twins) had no effect in cases of personal inde-pendent SLEs but affected the estimates by up to 50 per cent in cases of personal and network related SLEs.
} 
remarks do not question the inherent policy issue of the GxE evidence, i.e. that the identification of environmental risk factors may enable policies to improve these environments, and thereby in particular assist carriers of genetic risk. The main reservations are perhaps that results are typically based on relatively small samples and that GxG effects can not be completely ruled out. Future research is likely to further assess these aspects of the $\mathrm{GxE}$ evidence.

\section{B Other evidence of $\mathrm{GxE}$}

As was mentioned in the introduction, researchers have struggled to find a direct genetic link to IQ score. Caspi et al. (2007) used the fact that breastfeeding of children has been known to predict IQ scores later in life (Anderson et al. 1999, Mortensen et al. 2002). Controlling for intrauterine growth, social class and maternal cognitive ability, they found breastfeeding was significantly related to IQ, as was the interaction term between breastfeeding and their candidate gene type but not the gene type by itself. The gene was not associated with any of the covariates, but it had a moderating impact on the association between breastfeeding and IQ-score. Besides their Dunedin sample $(\mathrm{n}=858)$, they confirmed their findings by studying a British sample of same sex twins drawn from a 1994-1995 birth register $(\mathrm{n}=1772) .{ }^{13}$

Concerning the incidence of hyperactivity disorders ADHD, Kahn et al. (2003) showed a specific gene type increased the risk of ADHD if the mother had been smoking during pregnancy. Neuman et al. (2007) replicated the result, as did Becker et al. (2008) for males, controlling for postnatal smoke exposure and psychosocial adversity. Brookes et al. (2006) did not replicate the finding but instead found ADHD linked to prenatal alcohol use which exacerbated the genetic risk.

The evidence suggests that there may be more to gain from policies affecting home environments than previously thought. Thus, breastfeeding may compensate genetic risk factors associated with cognitive abilities, and keeping pregnant women away from drinking and smoking may compensate for genetic risks associated with conduct disorders.

Other examples of detected GxE interaction effects include Guo et al. (2008) who found an association between the number of sexual partners and a specific gene type, which did not hold in school environments where a high proportion started having sex early. Settle et al. (2008) found that for individuals with a specific gene variation, the number of friendships in adolescence was significantly associated with a liberal political ideology. The relation did not hold for individuals who did not have the specified genetic makeup. ${ }^{14}$ Caspi et al. (2005) examined cannabis use in adolescence, which is considered to be a weak risk factor for developing various psychotic symptoms such as schizophrenia. They found a genetic variant that was related to a significantly higher likelihood of psychotic symptoms following cannabis use in adolescence, whereas

\footnotetext{
${ }^{13}$ From the Environmental Risk Longitudinal Twin Study.

${ }^{14}$ The result lends some support to a controversial study by Alford et al. (2005) who, with a traditional twin study, found quite specific political preferences (on e.g. nuclear power, censorship, abortion laws) were de-termined by genetic heritage. See Charney (2008) for a discussion.
} 
another gene type was associated with no relation between cannabis use and psychotic symptoms. Shanahan et al. (2008) explored a genetic variant which has been associated with dysfunctional schooling. Among individuals with this gene type, they found a lower probability of engaging in tertiary level education, but the genetic risk was compensated by environments where parents had high socioeconomic status, were highly involved in school and the school itself was of high quality.

Besides behavioral traits, epidemiologists have recognized that genetically transferable diseases clustered in families most often also depend on environmental risk-factors. For example, exposure to smoking increases the risk for lung-cancer but the effect is moderated by gene types (Amos et al. 2008, Hung et al. 2008, Thorgeirsson 2008). Asthma is related to specific genes but the risks increase for children exposed to tobacco smoke early in life (Bouzigon et al. 2008) and decrease for children who attend day care during the first year (Hoffjan et al. 2005). Other fields include bacterial infections (malaria, streptococci), cardiovascular disease and type 2 diabetes, for references, including replications, see Moffitt et al. (2006, p8).

\section{Epigenetics}

Epigenetics concern heritable information outside the DNA sequence (the Greek prefix epi means "on" or "over"). Although DNA sequences remain unchanged, it has been shown that environmental factors may cause genes to "behave" differently; the term used is that they modify gene expression, and that such epigenetic modifications are heritable. ${ }^{15}$ Consequently, monozygotic twins differ significantly in their epigenetic profiles already when they are 5 years old (Mill et al. 2006) and the differences increase with age, and/or if they have a history of non-shared environments (Fraga et al. 2005, Oates et al. 2006). The implications of these studies include that heritable traits are not entirely "random" variants of the ancestors, but partly adapted to the environment.

The human longevity makes it difficult to collect historical data on behaviors and/or environments across generations. The epigenetic hypothesis is therefore easier to study on animals with short life-spans. Waterland and Jirtle (2003) studied the so called agouti mice. Its name stems from a particular gene, the agouti gene, which makes it prone to cancer and diabetes. By altering the diet of the mother just before conception, certain genes were switched off. The offspring was no longer susceptible to cancer or diabetes and lived much longer, and their different physical traits (color and size) and lower disease risks were passed on to the next generation. Similarly, Bertram et al. (2008) found that under-nutrition of pregnant guinea pigs affected the risk for cardiovascular disease across two generations. Evidence on animals outside gestation include Champagne et al. (2006) who reported from experiments on rats that increased grooming behavior of the mother altered gene

\footnotetext{
${ }^{15}$ The development of a fetus illustrates one example of changing gene expression. A fertilized egg takes new shapes, developing many cell types (venes, muscles etc) as it continues to divide through a process where some genes are activated while others are not.
} 
expression and induced a similar behavior in female offspring. This behavior was transmitted across generations. Recent evidence in Nätt et al. (2009) indicates that trained abilities may also be transmitted to the offspring. They found that chickens who were exposed to unpredictable food access adapted their strategies to better survive, and their offspring showed similar foraging behavior.

On humans, the famine during the winter of 1944-1945 in the Netherlands has been explored to study the effects of variation in nutrition during pregnancy (Painter et al. 2005, Lumey et al. 2007). It has been shown that the famine had detrimental health effects for the children and grandchildren of those mothers who were exposed. In analogy with the study on the agouti mice, one hypothesis is that a pregnant mother's diet can affect inherited traits through epigenetic influence and that higher disease risks may persist also for future generations. With a slightly different hypothesis in mind, Kaati et al. (2002) studied the occurrence of food shortage in northern Sweden by going through records of harvests and food prices during the 19th Century. They were especially interested in food supplies during children's so-called "slow growth period" (SGP) which occurs at age 8-10 for girls and 9-12 for boys. It turned out that individuals experiencing food shortages in the SGP, had descendants with lower risks of mortality from cardiovascular disease and diabetes (i.e. a period of fasting decreased descendants' risks). Pembrey et al. (2006) analyzed the effect of smoking during the SGP by exploring UK data from the Avon Longitudinal Study of Parents and Children, consisting of interviews with parents of newborn 1991-1992. Of the 5,000 fathers who had said they were smokers, 166 of them had stated they were regular smokers already during the SGP. They found that the sons of these fathers had higher body mass index as 9 year olds. Among the hypotheses to explain these findings, epigenetics is a major candidate but, of course, the evidence from studies of animals is more compelling.

\section{Concluding discussion}

To explain how human behavior and individual traits are developed, recent evidence from molecular genetic research has emphasized interactions between genes and environment, while genetic effects that operate independently of environmental conditions have been found surprisingly weak. Moreover, epigenetic findings suggest that environmental factors affect gene expressions which are heritable even though they are independent of the DNA sequence. If the current findings stand the test of time, molecular genetics may provide further strength to arguments for social interventions.

For economists concerned with how socioeconomic outcomes are generated, co-operation with geneticists is an interesting path. Identifying environmental risk factors, which in particular affect carriers of genetic risks, have egalitarian policy implications in the current generation, but will also increase intergenerational mobility if environmental and/or genetic risk factors are more prevalent among individuals from poor socioeconomic backgrounds.

Several authors provide guidelines for GxE research (Moffitt et al. 2006, 
Uher and McGuffin 2008). Major caveats include that GxE may develop in several stages, requiring longitudinal data, and that variations in environments are measured quite crudely compared with genetic variations. This suggests that relatively small samples, with more expensive measures of E, may be preferred to larger data sets. Simulations of measurement errors in Wong et al. (2003) indicate that if correlations with some true value of $E$ increase from .4 to .7 it corresponds to a 20 -fold increase in sample size. Of course, whether researchers uncover a direct genetic effect, a $\mathrm{GxE}$ or no effect depends on the variation in $\mathrm{E}$ and $\mathrm{G}$. If a genetic variant influences outcome only conditional on an $\mathrm{E}$ factor, it will emerge as a direct effect if $\mathrm{E}$ is very common or no effect if $\mathrm{E}$ is very rare, i.e. in order to detect $\mathrm{GxE}$, sufficient variation in $\mathrm{E}$ is required. Usually, however, environments vary greatly and even MZ twins who share the same class-room environment have been found to perceive it very differently (Asbury et al. 2008). Also, as traditional studies based on twins or adopted children have found genetic endowments to co-vary with most diseases, mental disorders and behavioral traits, it seems likely that the sensitivity to environmental factors would also partly depend on the genes. 


\section{References}

Alford, J., Funk, C. and Hibbing, J. (2005). Are Political Orientations Genetically Transmitted? American Political Science Review 99(2), 153-167.

Amos, C.I., Wu, W., Broderick, P. et al. (2008). Genome-wide Association Scan of Tag SNPs Identifies a Susceptibility Locus for Lung Cancer at 15q25.1. Nature and Genetics 40(5), 616-622.

Anderson, J.W., Johnstone,B.M. and Remley, D.T. (1999). Breast-feeding and Cognitive Development: A Meta-Analysis. American Journal of Clinical Nutrition 70, 525-535.

Asbury, K., Almeida, D., Hibel, J., Harlaar, N. and Plomin, R. (2008). Clones in the classroom: A Daily Diary Study of the Nonshared Environmental Relationship Between MZ Differences in School Experience and MZ Differences in School Achievement. Twin Research and Human Genetics 11(6), 686-695.

Becker, K., El-Faddagh, M., Schmidt, M., Esser, G. and Laucht, M. (2008). Interaction of Dopamin Transporter Genotype with Prenatal Smoke Exposure on ADHD Symptoms. The Journal of Pediatrics 152, 263-269.

Behrman, J. and Taubman, P. (1976). Intergenerational Transmission of Income and Wealth. American Economic Review 66, 436-440.

Behrman, J. and Taubman, P. (1989). Is Schooling "Mostly in the Genes"? Nature-Nurture Decomposition Using Data on Relatives. Journal of Political Economy 97(6), 1425-1446.

Bertram, C., Khan, O., Ohri, S., Phillips, D., Matthews, S. and Hanson, M. (2008). Transgenerational Effects of Prenatal Nutrient Restriction on Cardiovascular and Hypothalamic-Pituitary-Adrenal Function. Journal of Physiology 586(8), 2217-2229.

Björklund, A., Jäntti, M. and Solon, G. (2005). Influences of Nature and Nurture on Earnings Variation. A Report on a Study of Various Sibling Types in Sweden. In Bowles, S. Gintis, H. and Osborne, M. Unequal Chances: Family Background and Economic Success, Princeton, NJ, Princeton University Press.

Björklund, A., Jäntti, M. and Solon, G. (2007). Nature and Nurture in the Intergenerational Transmission of Socioeconomic Status: Evidence from Swedish Children and Their Biological and Rearing Parents. The B.E. Journal of Economic Analysis and Policy 7(2), article 4.

Björklund, A., Lindahl, M. and Plug, E. (2006). The Origins of Intergenerational Associations: Lessons from Swedish Adoption Data. Quarterly Journal of Economics 121, 999-1028.

Bouzigon, E., Corda, M.S., Hugues, A., Dizier, M.-H., Boland, A., Bousquet, J. et al. (2008). Effect of 17q21 Variants and Smoking Exposure in Early-Onset Asthma. The New England Journal of Medicine 359, 1985-1994.

Brookes, K.J., Mill, J., Guindalini, C., Curran, S., Xu, X., Knight, J. et al. (2006). A Common Haplotype of the Dopamine Transporter Gene Asociated with Attention-Deficit/Hyperactivity Disorder and Interacting with Maternal Use of Alcohol During Pregnancy. Archives of General Psychiatry 63, 74-81.

Brown, G.W. and Harris, T.O. (1978). Social Origins of Depression. A Study of Psychiatric Disorder in Women. 5th ed. Routledge, London.

Butcher, L.M., Davis, O.S.P., Craig, I.W. and Plomin, R. (2008). GenomeWide Quantitative Trait Locus Association Scan of General Cognitive Ability Using Pooled DNA and 500K Single Nucleotide Polymorphism Microarrays. 
Genes, Brain and Behavior 7, 435-446.

Cadoret, R.J., Winokur, D., Langbehn, E., Troughton, E., Yates, W.R. and Stewart, M.A. (1996). Depression Spectrum Disease I: The Role of Gene Environment Interaction. American Journal of Psychiatry 153, 892-899.

Case, A., Lin, F.I. and McLanahan, S. (2000). How Hungry is the Selfish Gene? Economic Journal 1110, 781-804.

Case, A., Lin, F.I. and McLanahan, S. (2001). Educational Attainment of Siblings in Stepfamilies. Evolution and Human Behavior 22, 269-289.

Caspi, A., McClay, J., Moffitt, T., Mill, J., Martin, J., Craig, I.W. (2002). Role of Genotype in the Cycle of violence in Maltreated Children. Science 297, 851-854.

Caspi, A., Sugden, K., Moffitt, T., Taylor, A., Craig, I.W. and Harrington, H. (2003). Influence of Life Stress on Depression: Moderation by a Polymorphism in the 5-HTT gene. Science 301, 386-389.

Caspi, A., Moffitt, T, Morgan, J., Rutter, M., Taylor, A. Arsenault, L. et al. (2004). Maternal Expressed Emotion Predicts Children's Antisocial Behavior Problems: Using Monozygotic Twin Differences to Identify Environmental Effects on Behavioral Development. Development Psychology 40, 149-161.

Caspi, A., Moffitt, T, Cannon, M., McClay, J., Murray, R., Harrington, H. et al. (2005). Moderation of the Effect of Adolescent-Onset Cannabis Use on Adult Psychosis by a Functional Polymorphism in the Catechol-OMethyltransferase Gene. Biological Psychiatry 57, 1117-1127.

Caspi, A., Williams, B., Kom-Cohen, J., Craig. I., Milne, B., Poulton, R. et al. (2007). Moderation of Breastfeeding Effects on the IQ by Genetic Variation in Fatty Acid Metabolism. Proceeding of the National Academy of Sciences of the United States of America 104(47), 18860-18865.

Cesarini, D., Dawes, C., Johannesson, M., Lichtenstein, P. and Wallace, B. (2009a). Genetic Variation in Preferences for Giving and Risk-Taking. Quarterly Journal of Economics 124(2), 809-842.

Cesarini, D., Johannesson, M., Lichtenstein, P. and Wallace, B. (2009b). Heritability of Overconfidence. Journal of the European Economic Association 7(2-3), 617-627.

Champagne, F.A., Weaver, I.C.G., diorio, J., Dymov, S., Szyf, M. and Meaney, M.J. (2006). Maternal Care Associated with Methylation of the Estrogen Receptor- $\alpha 1 \mathrm{~b}$ promoter and Estrogen Receptor- $\alpha$ Espression in the Medial Preoptic Area of Female Offspring. Endocrinology 147(6), 2909-2915.

Charney, E. (2008). Genes and Ideologies. Perspectives on Politics 6(2), 299-319.

Covault, J., Tennen, H., Armeli, S., Conner, T.S., Herman, A.I. and Cillessen, A.H. et al. (2006). Interactive Effects of the Serotonin Transporter 5-HTTLPR Polymorphism and Stressful Life Events on College Student Drinking and Drug Use. Biological Psychiatry 61, 609-616.

Cunha, F. and Heckman, J.J. (2009). The Economics and Psychology of Inequality and Human Development. Journal of the European Economic Association 7(2-3), 320-364.

Dickens, W. and Flynn, J. (2001). Heritability Estimates Versus Large Environmental Effects: The IQ Paradox Resolved. Psychological Review 108(2), 346-369. 
Durrant, J.E. and Janson, S. (2005). Law Reform, Corporal Punishment and Child Abuse: The Case of Sweden. International Review of Victimology 12(2), 139-158.

Foley, D.L., Craig, J., Morley, R., Olsson, C., Dwyer, T. Smith, K. and Saffery, R. (2009). Prospects for Epigenetic Epidemiology. American Journal of Epidemiology 169, 389-400.

Foley, D.L., Eaves, L.J., Wormley, B., Silberg, J.L., Maes, H.H. and Kuhn, J. (2004). Childhood Adversity, monoamine Oxidase A Genotype and Risk for Conduct Disorder. Archives of General Psychiatry 61(7), 738-744.

Fraga, M.F., Ballestar, E., Paz, M.F., Ropero, S., Setien, F. et al. (2005). Epigenetic Differences Arise During the Lifetime of Monozygotic Twins. Proceeding of the National Academy of Sciences of the United States of America 102, 10604-10609.

Franke, B., Neale, B. and Faraone, S. (2009). Genome-Wide Association Studies in ADHD. Human Genetics. In press.

Goldberger, A. (1979). Heritability. Economica 46, 327-347.

Goldstein, D. (2009). Common Genetic Variation and Human Traits. New England Journal of Medicine 360(17), 1696-1698.

Guo, G., Yuying, T. and Tianji, C. (2008). Gene by Social Context Interactions for Number of Sexual Partners among White Male Youths: GeneticsInformed Sociology. American Journal of Sociology 114, 36-66.

Guo, G. and Stearns, E. (2002). The Social Influences on the Realization of Genetic Potential for Intellectual Development. Social Forces 80(3), 881-910.

Haberstick, B., Lessem, J., Hopfer, C., Smolen, A., Ehringer, M., Tiimberlake, D. and Hewitt, J. (2005). Monoamine Oxidase A (MAOA) and Antisocial Behaviors in the Presence of Childhood and Adolescent Maltreatment. American Journal of Medical Genetics Part B (Neuropsychiatric Genetics) 135B: 59-64.

Harden, K.P., Turkheimer, E. and Loehlin, J.C. (2007). Genotype by Environment Interactions in Adolescents' Cognitive Aptitude. Behavioral Genetics 37, 273-283.

Heckman,J.J. (2007). The Economics, Technology, and Neuroscience of Human Capability Formation. Proceeding of the National Academy of Sciences of the USA 104, 13250-13255.

Heckman,J.J. (2008). Schools, Skills, and Synapses. IZA Working Paper3515.

Hirschhorn, J. (2009). Genomewide Association Studies - Illuminating Biologic Pathways. New England Journal of Medicine 360(17), 1699-1701.

Hoffjan, S., Nicolae, D., Ostrovnaya, I., Roberg, K., Evans, M., Mirel, D. et al. (2005). Gene-Environment Interaction Effects on the Development of Immune Responses in the 1st Year of Life. American Journal of Human Genetics 76, 696-704.

Horwitz, A., Videon, T., Schmitz, M. and Davis, D. (2003). Rethinking Twins and Environments: Possible Social sources for Assumed Genetic Influences in Twin Research. Journal of Health and Social Behavior 44, 111-129.

Huizinga, D., Haberstick, B., Smolen, A., Menard, S. et al. (2006). Childhood Maltreatment, Subsequent Antisocial Behavior, and the Role of Monoamine Oxidase A Genotype. Biological Psychiatry 60, 677-683. 
Hung, R.J., McKay, J.D., Gaborieau, V. et al. (2008). A Susceptibility Locus for Lung Cancer Maps to nicotinic Acetylcholine receptor Subunit Genes on 15q25. Nature 452(7187), 633-637.

Jencks, C. (1980). Heredity, Environment, and Public Policy Reconsidered. American Journal of Sociology 45, 723-736.

Joseph, J. (2002). Twin Studies in Psychiatry and Psychology: Science of Pseudoscience? Psychiatric Quarterly 73(1), 71-82.

Kaati, G., Bygren, L.O. and Edvinsson, S. (2002). Cardiovascular and Diabetes Mortality Determined by Nutrition During Parents' and Grandparents' Slow Growth Period. European Journal of Huan Genetics 10, 682-688.

Kahn, R., Khoury, J., Nichols, W. and Lanphear, B. (2003). Role of Dopamine Transporter Genotype and Maternal Prenatal Smoking in Childhood Hyperactive-Impulsive, Inattentive, and Oppositional Behaviors. The Journal of Pediatrics 143, 104-110.

Kaufman, J., Yank, B-Z., Douglas-Palumberi, H. et al. (2007). Genetic and Environmental Predictors of Early Alcohol Use. Biological Psychiatry 61, 1228-1234.

Kendler, K.S., Kessler, R.C., Walters, E.E., MacLean, C., Neale, M.C. et al. (1995). Stressful life events, genetic liability, and onset of an episode of major depression in women. American Journal of Psychiatry 152(6), 833-842.

Kendler, K.S., Karkowski, L.M. and Prescott, C.A. (1999a). Causal Relationship Between Stressful Life Events and the Onset of Major Depression. American Journal of Psychiatry 156(6), 837-841.

Kendler, K.S., Karkowski, L.M. and Prescott, C.A. (1999b). The Assessment of Dependence in the Study of Stressful Life Events: Validation Using a Twin Design. Psychological Medicine 29, 1455-1460.

Lehn, H., Derks, E.M., Hudziak, J.J., Heutink, P., van Beijsterveldt, T.C.E.M. and Boomsma, D.I. (2007). Attention Problems and Attention-Deficit/Hyperactivity Disorder in Discordant and Concordant Monozygotic Twins: Evidence of Environmental Mediators. Journal of the American Academy of Child and Adolescent Psychiatry 46, 83-91.

Liu, H. and Zeng, J. (2009). Genetic Ability and intergenerational Earnings Mobility. Journal of Population Economics 22, 75-95.

Lumey, L.H., Stein, A., Kahn, H., van der Pal-de Bruin, K., Blauw, G.J., Zybert, P. and Susser, E. (2007). Cohort Profile: The Dutch Hunger Winter Families Study. International Journal of Epidemiology 36, 1196-1204.

McGue, M. (2008). The End of Behavioral Genetics? Acta Psychologica Sinica 40(10), 1073-1087.

Meaburn, E.L., Harlaar, N., Craig, I.W., Schalkwyk, L.C. and Plomin, R. (2008). Quantitative Trait Locus Association Scan of Early Reading Disability and Ability Using Pooled DNA and 100K SNP Microarrays in a Sample of 5760 Children. Molecular Psychiatry 13, 729-740.

Meltzer, H. (1989). Serotonergic Dysfunction in Depression. British Journal of Psychiatry, Supplement 155, 25-31.

Mill, J., Dempster, E., Caspi, A., Williams, B., Moffitt,T. and Craig, I. (2006). Evidence for Monozygotic twin Discordance in Methylation Level at two CpG Sites in the Promoter Region of the Catechol-O-methyltransferase gene. American Journal of Medical Genetics 141, 421-425. 
Mill, J. and Petronis, A. (2007). Molecular Studies of Major Depressive Disorder: The Epigenetic Perspective. Molecular Psychiatry 12, 799-814.

Mill, J. and Petronis, A. (2008). Pre- and peri-natal Environmental Risks for Attention-Deficit Hyperactivity disorder (ADHD): the Potential role of Epigenetic Processes in Mediating Susceptibility. Journal of child Psychology and Psychiatry 49(10), 1020-1030.

Moffitt, T. Caspi, A. and Rutter, M. (2006). Measured Gene-Environment Interactions in Psychpathology. Perspectives on Psychological Science 1(1), $5-27$.

Mortensen, E.L., Michaelsen,K.F., Sanders, S.A. and Remich, J.M. (2002). Association Between Duration of Breastfeeding and Adult Intelligence. Journal of the American Medical Association 287(19), 2365-2371.

Nätt, D., Lindqvist, N., Stranneheim, H., Lundeberg, J., Torjesen, P. and Jensen, P. (2009). Inheritance of Acquired Behavior Adaptations and Brain Gene Expression in Chickens. PLoS OnE 4(7), e6405.

Neuman, R., Lobos, E., Reich, W., Henderson, C., Sun, L-W and Todd, R. (2007). Prenatal Smoking Exposure and Dopaminergic Genotypes Interact to Cause a Svere ADHD Subtype. Biological Psychiatry 61, 1320-1328.

Nilsson, K.W., Sjöberg, R.L., Damberg, M., Alm, P.O.,Ohrvik, J., Leppert, J. et al. (2005). Role of the Serotonin Transporter Gene and Family Function in Adolescent Alcohol Consumption. Alcoholism: Clinical and Experimental Research 29, 564-570.

Oates, N.A., Van Vliet, J., Duffy, D.L., Kroes, H.Y., Martin, N.G., Boomsma, D.I. (2006). Increased DNA Methylation at the AXIN1 Gene in a Monozygotic Twin from a Pari Discordant for a Caudal Duplication Anomaly. American Journal of Human Genetics 79, 155-162.

Oliver, B., Pike, A. and Plomin, R. (2008). Nonshared Environmental Influences on Teacher-Reported Behavior Problems: Monozygotic Twin Differences in Perceptions of the Classroom. Journal of Child Psychology and Psychiatry 49(6), 646-653.

Painter, R., Roseboom, T. and Bleker, O. (2005). Prenatal Exposure to the Dutch Famine and Disease in Later Life: An Overview. Reproductive Toxicology 20, 345-352.

Paykel, E.S. (1997). The Interview for Recent Life Events. Psychological Medicine 27, 301-310.

Pearson T. and Manolio, T. (2008). How to Interpret Genome-Wide Association Study. Journal of the American Medical Association 299(11), 13351344

Pembrey, M., Bygren, L.O., Kaati, G., Edvinsson, S., Northstone, K., Sjöström, M. and Golding, J. (2006). Sex-Specific, Male-Line Transgenerational Responses in Humans. European Journal of Human Genetics 14, 159166.

Plug, E. and Vijverberg, W. (2003). Schooling, Family Background and Adoption: Is It Nature of Is It Nurture? Journal of Political Economy 111, 611-641.

Polanczyk, G., de Lima, M.S., Horta, B.L., Biederman, J. and Rhode L.A. (2007). The Worldwide Prevalence of ADHD: A Systematic Review and Metaregression Analysis. American Journal of Psychiatry 164, 942-948. 
Reif, A., Rosler, M., Freitag, C.M., Schneider, M., Eujen, A. and Kissling, C. (2007). Nature and Nurture Predispose to Violent Behavior: Serotonergic Genes and Adverse Childhood Environment. Neuropsychopharmacology 32, 2375-2383.

Reiss, D. (2008). Social Processes and Genetic Influences in Child Development: Novel Uses of Twin and Adoption Designs. Acta Psychologica Sinica 40(10), 1099-1105.

Richardson, K. and Norgate, S. (2006). A Critical Analysis of IQ Studies of Adopted Children. Human Development 49, 319-335.

Rowe, D.C., Jacobson, K.C. and van den Oord, E. (1999). Genetic and Environmental Influences on Vocabulary IQ: Parental Education Level as Moderator. Child Development 70(5), 1151-1162.

Rutter, M. and Silberg, J. (2002). Gene-Environment Interplay in Relation to Emotional and Behavioral Disturbance. Annual Review of Psychology 53, 463-490.

Sacerdote, B. (2002). The Nature and Nurture of Economic Outcomes. American Economic Review 92, 344-348.

Sacerdote, B. (2007). How Large Are the Effects from changes in Family Environment? A Study of Korean American Adoptees. Quarterly Journal of Economics 122, 119-157.

Scarr, S. and Weinberg, R. (1994). Educational And Occupational Achievements Of Brothers And Sisters In Adoptive And Biologically Related Families. Behavior Genetics 24, 301-325.

Settle, J., Dawes, C. Hatemi, P. Christakis, N. and Fowler, J. (2008). Friendships Moderate an Association Between a Dopamine Gene Variant and Political Ideology. Paper presented at the annual meeting of the APSA 2008, Boston.

Shanahan, M., Vaisey, S., Erickson, L. and Smolen, A. (2008). Environmental contingencies and Genetic Propensities: Social Capital, Educational Continuation and Dopamine Receptor Gene DRD2. American Journal of Sociology 114, 260-286.

Smith, S.L., Howard, J.A. and Monroe, A.D. (2000). Issues Underlying Behavior Problems in at-risk Adopted Children. Children and Youth Services Review 22, 539-562.

Stoolmiller, M. (1999). Implications of the Restricted Range of Family Environments for Estimates of Heritability and Non-shared Environment in Behavior-genetic Adoption Studies. Psychological Bulletin 125, 392-409.

Taubman, P. (1976). The Determinants of Earnings: Genetics, Family and Other Environments; A Study of White Male Twins. American Economic Review 66(5), 858-870.

Taylor, A. and Kim-Cohen (2007). Meta-Analysis of gene-Environment Interactions in Developmental Psychopathology. Development and psychopathology 19(4), 1029-1037.

Thapar, A. and Stergiakouli, E. (2008). An Overview of the Genetics of ADHD. Acta Psychologica sinica 40(10), 1088-1098.

Thorgeirsson, T.E., Geller, F., Sulem, P et al. (2008). A Variant Associated with Nicotine Dependence, Lung Cancer and Peripheral Arterial Disease. Nature 452(7187), 638-642. 
Turkheimer, E., Haley, A., Waldron, M., D’Onofrio, B. and Gottesman, I. (2003). Socioeconomic Status Modifies Heritability of IQ in Young Children. Psychological Science, 14(6), 623-628.

Uher, R. and McGuffin, P. (2008). The Moderation By the Serotonin Transporter Gene of Environmental Adversity in the Aetiology of mental Illness: Review and Methodological Analysis. Molecular Psychiatry 13(2), 131146.

Wallis, D., Russell, H. and Muenke, M. (2008). Review: Genetics of Attention Deficit/Hyperactivity Disorder. Journal of Pediatric Psychology 33(10), 1085-1099.

Waterland, R. and Jirtle, R. (2003). Transposable Elements: Targets for Early Nutritional Effects on Epigenetic Gene Regulation. Molecular and Cellular Biology 23(15), 5293-5300.

Weedon, M.N., Lango, H., Lindgren, C.M. et al. (2008). Genome-Wide Association Analysis Identifies 20 Loci that Influence Adult Height. Nature Genetics 40, 575-583.

Wong, M.Y., Day, N.D., Luan, J.A. and Wareham, N.J. (2003). The Detection of Gene-Environment Interaction for Continuous Traits: Should We Deal with Measurement Error by Bigger Studies or Better Measurement? International Journal of Epidemiology 32(1), 51-57.

Young, S.E., Smolen, A., Hewitt, J.K., Haberstick, B.C., Stallings, M.C., Corley, R.P. et al. (2006). Interaction Between MAO-A Genotype and Maltreatment in the Risk for Conduct Disorder: Failure to Confirm in Adolescent Patients. American Journal of Psychiatry 163, 1019-1025. 